\title{
A study on the Quality of Environmental Disclosures of China's Circular Economy Listed Companies
}

\author{
Cheng-zhi Liu ${ }^{1, a}$ \\ ${ }^{1}$ The accounting department of Shaoyang University, \\ China \\ aliucz1976@126.com
}

\author{
Fei-zhou Liu'b \\ ${ }^{2}$ The library of Shaoyang University, China \\ bliufz1980@126.com
}

\author{
Ti-yu Xie ${ }^{3, c}$ \\ ${ }^{3}$ The accounting department of Shaoyang University, China \\ cxietf1972@126.com
}

\begin{abstract}
This paper takes 12 circular economy listed companies commended by the National Development and Reform Commission of China in 2012 as the samples, using content analysis to evaluate the quality status of their environmental disclosure objectively. The study finds that in the environmental disclosures of China's listed companies there exist such problems as: monetary measurement information is in deficiency, the degree of negative disclosures is relatively low, the overall quality level of the disclosures needs to be improved. Some improvement suggestions are given from constructing disclosure systems, implementing environmental management accounting and strengthening supervision to circular economy listed companies.
\end{abstract}

Keywords-circular economy; listed company; environmental disclosure; quality evaluation

\section{INTRODUCTION}

As great environmental pollution accidents occur frequently and the public's awareness of environmental protection is increasing constantly in recent years. ${ }^{[1]}$ under the active push of the Ministry of Environmental Protection, China's Securities Regulatory Commission and relevant departments, more and more listed companies disclose their environmental information through various channels. The whole society pays more and more attention to companies' environmental disclosures. The environmental disclosure of listed companies has also become an important gauge for investors to evaluate company risk and future cash flow. The quality of environmental disclosure is overall in the continuous improvement process. ${ }^{[2]}$ In the field of companies' environmental disclosure, the performance of circular economy listed companies is more typical and exemplary. As a circular economy listed company, the high quality disclosure of environmental information is not only an important way to embody their environmental responsibility to be implemented, but an important means to enhance their company value. ${ }^{[3]}$ This paper takes some outstanding circular economy listed companies as samples, evaluates the quality status of their environmental disclosures, reveals the existed problems and puts forward improvement suggestions.

\section{THE DEVELOPMENT OF CIRCULAR ECONOMY AND THE DISCLOSURE OF ENVIRONMENTAL INFORMATION}

In, China, developing circular economy is an important strategic decision, a major initiative to promote ecological civilization construction and also an inevitable choice to speed up the transformation of economic development mode, to construct a resource-saving, environment-friendly society and then to realize sustainable development. In the Eleventh Five-Year period, China took developing circular economy as a major task of the national economic and social development. Enterprises are demanded to follow the principles of decrement, reuse and resourcelization to promote the development of circular economy in each link of production, circulation, consumption. Two batches of national circular economy pilot were carried out and a large number of circular economy enterprises emerged in key industries, key fields, industrial parks, provinces and cities. In 2012 December, the State Council issued "the Twelfth Five Year development plan for circular economy", which further clarifies that circular economy will be the focus of the Twelfth Five Year development in national economy; In 2013 March, the State Council issued "the circular economy development strategy and the short-term action plan", which proposed building "a system for circular industry, agriculture and service" and "cultivating 1000 circular economy demonstration enterprises", which made the development of circular economy companies usher in another important strategic opportunities. As China advocates the development of circular economy companies strongly, which also arouse general attention to circular economy companies in the whole society. The essence of circular economy is ecological economy and green economy. So circular economy companies should follow the development mode to harmony with environment more strictly than ordinary companies. Meanwhile, they should enjoy the state's preferential policies in the planning, credit, 
investment, finance, government procurement and tax etc. Therefore, in the performance of environmental responsibility and disclosure of environmental information, the social public put forward more demands and higher expectations to circular economic companies. At the same time, listed companies usually occupy leading status at scale, benefit, technology in their industries, "the instruction opinions on strengthening environmental supervision and management work for listed companies" issued by the State Environmental Protection Administration of China in 2008 put forward requirements for mandatory and voluntary disclosure clearly. As circular economy listed companies, they should follow the guidance provisions and the regulations of the evaluation

In 2012 December, China National Development and Reform Commission commended 76 national advanced units at circular economy work. This is the first time to commend enterprises in the field of circular economy in China, the twelve companies which are commended are on behalf of the highest level of China's listed companies in the sustainable utilization of resources, environmental protection and the coordinated development of the operation and management, and play a good demonstration in their respective industry. This paper uses the twelve listed companies above as samples, then collects and sorts data and documents related to environmental disclosure according to their annual reports, social responsibility index system for circular economy, disclose their policies, measures and achievements initiatively in the process of developing circular economy, and convey positive environmental information to enhance their companies' social images. Unfortunately, empirical researches at home in recent years indicated that the present quality of environmental disclosure in china's companies is not optimistic. There exist problems that the contents are nonobjective, the forms are irregular and the useful value is lower.

\section{THE QUALITY STATUS OF ENVIRONMENTAL DISCLOSURE}

report and sustainable development report or independent environmental report, then evaluates and analyzes the quality status of environmental disclosure by content analysis. According to the relevant requirements for environmental disclosure of China's listed companies, the contents of quality evaluation of environmental disclosure about listed companies can be divided into 7 first class indexes and 22 second class indexes. The 7 first class indexes include the carriers of disclosure, environmental managements, environmental costs, environmental debts, environmental investments, environmental achievements and environmental supervision etc (see Table I).

TABLE I. THE INDEXES OF QUALITY EVALUATION FOR COMPANIES’ ENVIRONMENTAL DiSCLOSURE

\begin{tabular}{|c|c|c|c|}
\hline first class index & second class index & first class index & second class index \\
\hline \multirow{3}{*}{$\begin{array}{l}\text { the carriers of } \\
\text { disclosure }\end{array}$} & enterprise's annual report & \multirow{2}{*}{$\begin{array}{l}\text { environmental } \\
\text { investments }\end{array}$} & the total investment of environmental assets \\
\hline & CSR & & $\begin{array}{l}\text { The expenditure used in the development of } \\
\text { environmental technology }\end{array}$ \\
\hline & $\begin{array}{c}\text { sustainable development report, environmental } \\
\text { report }\end{array}$ & \multirow{6}{*}{$\begin{array}{l}\text { environmental } \\
\text { achievements }\end{array}$} & the implementation of cleaner production \\
\hline \multirow{3}{*}{$\begin{array}{l}\text { environmental } \\
\text { managements }\end{array}$} & $\begin{array}{l}\text { the construction and operation of the environmental } \\
\text { management system }\end{array}$ & & the compliance rate of major pollutants discharge \\
\hline & $\begin{array}{c}\text { the implementation of environmental management } \\
\text { accounting }\end{array}$ & & $\begin{array}{l}\text { the comprehensive utilization rate of industrial } \\
\text { solid wastes }\end{array}$ \\
\hline & $\begin{array}{l}\text { environmental education, training and } \\
\text { communication }\end{array}$ & & $\begin{array}{l}\text { the reduction of comprehensive energy } \\
\text { consumption }\end{array}$ \\
\hline \multirow{2}{*}{$\begin{array}{l}\text { environmental } \\
\text { costs }\end{array}$} & the consumption of main raw materials & & the completion of total emission reduction task \\
\hline & the consumption of main energy & & $\begin{array}{c}\text { the awards and recognition achieved for } \\
\text { environmental protection }\end{array}$ \\
\hline \multirow{3}{*}{$\begin{array}{l}\text { environmental } \\
\text { debts }\end{array}$} & the amount of wastewater generated & \multirow{3}{*}{$\begin{array}{l}\text { environmental } \\
\text { supervisions }\end{array}$} & the certification of environment mark \\
\hline & the emissions of major pollutants & & $\begin{array}{c}\text { the implementation of the "three simultaneity" } \\
\text { system }\end{array}$ \\
\hline & the emissions of greenhouse gases & & environmental audits \\
\hline
\end{tabular}

The evaluation for second class indexes can take the following scoring criteria: the disclosure of second class indexes like the carrier, if enterprises issue only annual report, they'll score 1 . If they issue the social responsibility report as well as environmental information, they'll score 2 . If they issue sustainable development reports or independent environmental report at the same time, they'll score 3. The disclosure of second class indexes like environmental management, those companies that don't disclose it will score 0 ; those that make general disclosure will score 1 ; those that made detailed disclosure will score 2. The disclosure of second class indexes like 
environmental cost, debt, investment and achievement, those that don't disclose it score 0 , those that only make qualitative description score 1 , those that disclose through both quantitative and qualitative description, but inadequate, score 2 , Those that make both quantitative and qualitative description, as well as make detailed disclosure score 3.The disclosure of second class indexes like environmental supervision, those that don't disclose it score 0 , those that disclose it score 1 . After we score and summarize the 22 second class indexes in each sample companies, we'll get the EID of the quality of environmental disclosure for each sample company. In order to reflect the relative degrees of the twelve companies' environmental disclosure, we should count the maximum score of environmental disclosure in each sample company as 54(the disclosures of the index like carriers score 3,the disclosures of the index like environmental managements score 6 , the disclosures of the indexes like environmental costs, debts, investments and achievements score 42, the disclosures of the index like environmental supervisions score 3 ), then we can use the actual score to divide by the maximum score, we'll get the EIDI for the company. The calculation formula: EIDI $=100 \times(\mathrm{EID} / 54)($ table II $)$.

TABLE II. THE QUALITY EVALUATION OF ENVIRONMENTAL DISCLOSURE FOR THE 12 LISTED COMPANIES

\begin{tabular}{|c|c|c|c|c|c|c|c|c|c|}
\hline Stock code & $\begin{array}{l}\text { disclosure } \\
\text { carriers }\end{array}$ & $\begin{array}{l}\text { environme } \\
\text { ntal } \\
\text { manageme } \\
\text { nts }\end{array}$ & $\begin{array}{c}\text { environme } \\
\text { ntal } \\
\text { costs }\end{array}$ & $\begin{array}{c}\text { environme } \\
\text { ntal } \\
\text { debts }\end{array}$ & $\begin{array}{l}\text { environme } \\
\text { ntal } \\
\text { investment } \\
\mathrm{s}\end{array}$ & $\begin{array}{l}\text { environme } \\
\text { ntal } \\
\text { achieveme } \\
\text { nts }\end{array}$ & $\begin{array}{l}\text { environme } \\
\text { ntal } \\
\text { supervisio } \\
\text { ns }\end{array}$ & EID & EIDI \\
\hline 600881 & 2 & 3 & 3 & 3 & 3 & 10 & 2 & 25 & 46.30 \\
\hline 600549 & 2 & 1 & 1 & 1 & 3 & 8 & 0 & 16 & 29.63 \\
\hline 600600 & 3 & 6 & 8 & 7 & 5 & 15 & 3 & 47 & 87.04 \\
\hline 601005 & 2 & 1 & 1 & 1 & 2 & 5 & 0 & 12 & 22.22 \\
\hline 600497 & 3 & 5 & 7 & 6 & 5 & 13 & 2 & 41 & 75.93 \\
\hline 600096 & 2 & 5 & 5 & 5 & 4 & 12 & 2 & 35 & 64.81 \\
\hline 600227 & 2 & 4 & 1 & 1 & 3 & 5 & 0 & 16 & 29.63 \\
\hline 600075 & 2 & 3 & 2 & 1 & 3 & 8 & 1 & 20 & 37.04 \\
\hline 000898 & 2 & 4 & 2 & 2 & 4 & 9 & 1 & 24 & 44.44 \\
\hline 600019 & 3 & 5 & 7 & 7 & 5 & 13 & 2 & 42 & 77.78 \\
\hline 000878 & 2 & 1 & 1 & 1 & 2 & 6 & 1 & 14 & 25.93 \\
\hline 000786 & 2 & 2 & 2 & 3 & 3 & 6 & 0 & 18 & 33.33 \\
\hline
\end{tabular}

Data source: sorted according to the annual reports, CSRs, sustainable development reports and environmental reports issued by the twelve listed companies.

\section{THE QUALITY EVALUATION OF ENVIRONMENTAL DISCLOSURE}

\section{A. The overall level of disclosure needs to be improved}

All twelve sample companies disclosed their environmental information, which shows that China's circular economy listed companies generally carry out the provisions of "plans to open environmental information (for Trial)”(2007) and other relevant laws and regulations. The mean value of environmental disclosure indexes in the sample companies is 47.87, the standard deviation is 17.57, which shows that the overall level of disclosure in China's circular economy listed companies is low and uneven, and the gap between each other is larger. Besides the annual report, all sample companies disclose their environmental information through the social responsibility report, sustainable development report or environmental report, which shows circular economic listed companies mostly pay more attention to social responsibility and fostering a good image of sustainable development. Among them, Tsingtao, Baosteel and Chihong Zn\&Ge whose disclosure quality of environmental information are good issue both "sustainable development report" and "the independent environmental report" in 2012, which shows that the change of the carriers of environmental disclosure has marked influence on the quality of environment disclosure. In addition, only 1 in the samples conducts environmental audits to the environmental information disclosed, the majority lack of the disclosure of environmental certification and the disclosure of commendation and award accepted on the contributions to the environment, which indicates that the environmental information disclosed by sample companies is poor independence, meanwhile the government, institutions and agencies have a lower comprehensive evaluation for companies' 
environmental achievements, which affects the quality of company's environmental disclosure indirectly. In general, the quality of environmental disclosure in circular economy listed company has larger space to promote.

\section{B. The lack of monetary measurement environmental information}

If we take the forms of environmental disclosure as the basis of classification, the disclosure of companies' environmental information can be divided into text described, physical measurement and monetary measurement. Because most of the sample companies' environmental management accounting is missing or the strength of implementation is not enough, their environmental information is mainly disclosed in forms of text and physical form, while the information monetized is rare. These indexes like environmental costs, debts, investments and achievements which are relatively easy to make monetization treatment, most companies only reflect the monetary measurement in the indexes of environmental investments. Those that do well in monetization disclosure are Baosteel and Tsingtao etc. For example, Baosteel divided annual cost to protect environment into two parts, namely, the expensization cost and capitalization cost. In addition, they disclose the detailed items of the cost for protecting environment, and explained the major items. The monetary description of environmental information reflects the companies' environmental management achievements clearly. Which is also conducive to information users to overcome difficulties to make static lateral comparison among different companies, evading the differences between the different companies' environmental inputs (resources and energy input) and output (expectation and non expected outputs) .

\section{The disclosure for negative environmental information is lower}

After analyzing the disclosure of the five indexes, namely environmental managements, costs, debts, investments and achievements in the twelve sample companies, we found the disclosures for environmental managements, investments and achievements are higher, while the disclosures of environmental costs and debts are lower. " plans to open environmental information (for Trial )” (2007) encourage enterprises to disclose environmental managements, costs, debts, investments and achievements voluntarily, but demand the heavy pollution enterprises to disclose their environmental costs and debts. From the analysis of the disclosure of the twelve companies, the disclosure of environmental managements, investments and achievements were 55.56\%, 58.33\% and $50.92 \%$ respectively, and the disclosures of environmental costs and debts are $37.04 \%$ and $35.19 \%$ respectively. It is not difficult to find that the information of environmental costs and debts reflects the absolute degree of the companies' the resources, energy consumption and environmental pollution. All 12 sample companies belong to heavy pollution industry companies defined by "the disclosure guidance for listed companies (the draft)"
(2010). But according to the disclosure of the environmental costs, they didn't disclose the energy consumption, total water, standard coal etc per unit of GDP; According to the disclosure of environmental debts, only three companies disclosed the production of wastewater, four disclosed the emissions of pollutants concretely and only one disclosed the emissions of greenhouse gases concretely. Obviously, these sample companies do not carry out the relevant provisions of "plans to open environmental information for listed enterprises strictly (for Trial)" (2007), which made information users unable to learn the environmental debts these companies should bear comprehensively through environmental costs and debts.

\section{SUGGESTIONS ABOUT IMPROVING ENVIRONMENTAL DISCLOSURE}

\section{A. To perfect the system of environmental disclosure}

The construction of the environmental disclosure system is the foundation to improve the disclosure quality of circular economy listed companies. Firstly, the disclosure system of environmental information for these companies should be improved as soon as possible. The related implementation regulations or specific application guidelines should be issued. At present China's companies mostly disclose their environmental information voluntarily, only a few heavy pollution industries and listed companies are demanded to disclose their environmental information. And only the routines such as the annual summary, data reporting were established, and specific provisions for these companies' environmental disclosure weren't made. According to the rules and characteristics of listed company to develop circular economy, if they meet the general content of companies' environmental disclosure, we can design the content of disclosure and evaluation standards for circular economy listed companies based on the requirements of evaluation index system, we can also offer norms which are more specific, detailed and consistent with the characteristics of the development of circular economy, to improve the internal quality of disclosure. Thirdly, we should increase the system design and constraint for mandatory disclosure. Because the public's ability to identify the authenticity of environmental information is relatively low, if we let enterprises decide which to be disclosed, it may induce enterprises to cheat. It is better to avoid it at the very beginning than to administer it when the problem appears. If uniform provisions on disclosure form, time, contents and methods are made through the mandatory disclosure, may made the environmental information disclosed more comparable and useful in the whole industries or the whole country.

\section{B. To promote the environmental management accounting vigorously}

Promoting the environmental management accounting vigorously is the key to improve the quality of relevant disclosures. Promoting the environmental management 
accounting to realize management of accounting in companies' environmental business is the premise and key to realize the monetization of environmental disclosure. According to the characteristics of the companies to develop circular economy, the accounting contents of environmental accounting in circular economy listed companies should embody its own characteristics. At first it should reflect the financial effect produced by the production and operation which were organized according to the principle of "reduction, reuse and resource oriented". Namely, the positive or negative influences on the companies' financial position, operating results and cash flow that caused by circular economy activities, because of the reducing use of natural resources in the relevant accounting period. Secondly, it should reflect the financial impacts generated by carrying out the laws and regulations of circular economy. That is to say, observing the relevant laws and regulations for circular economy enterprises issued by various government sectors, to obtain the benefits of policy or system in financial, tax and other aspects, and the beneficial effect caused by enterprises on financial situation, cash flow and operating results. At last, it should reflect the financial impacts caused by the companies' ecological environmental activities. Namely, the positive and negative influences on their financial situation, cash flow and operating results caused by the ecological environment that they depended on during the process of production and operation. The calculation management of enterprises routine circular economy through environment management accounting, confirm, measure and record the related environmental costs, debts and incomes effectively, make full preparations of the original accounting data to improve the environmental disclosure quality effectively .

\section{To strengthen the supervision of environmental disclosure}

Strengthening supervision is the security to improve the quality of environmental disclosure in circular economy listed companies. The supervision and management mechanisms participated by the government, institutions and public should be built. Firstly, the government should adopt clearer and more effective punishment for those circular economy listed companies that have not disclosed their environmental information or have not disclosed their environmental information as required. Meanwhile, they should inspire circular economy listed companies by means of fiscal, investment, credit and tax policies to improve the disclosure quality. Secondly, the independent organisms and recognized organizations should carry out the third part independent audit carried out by social intermediary organizations, to improve the authenticity of environmental disclosure; the social recognized organization should make grade evaluation for environmental achievements and environmental disclosures. And establish the market access system based on evaluated grade for circular economy companies and its products. Thirdly, we should raise the public's awareness of environmental protection and strengthen the concept of developing circular economy vigorously and improve the investors' structure in China's circular economy listed companies gradually, then form multi-level investors as effective information demanders to increase the source of power to disclose the environmental information. We can train the majority of investors' consciousness of demanding high quality environmental information through various channels and ways and establish internal motivation and external pressure mechanisms for circular economy listed companies to disclose environmental information voluntarily or compulsively.

\section{ACKNOWLEDGMENT}

A Project Supported by Scientific Research Fund of Hunan Provincial Education Department (No:14A130).

\section{CORRESPONDING AUTHOR}

Cheng-zhi Liu, liucz1976@126.com, 13973991022.

\section{REFERENCES}

[1] J.Wiseman. An evaluation of environmental disclosures made in corporate annual reports. Accounting Organisations and Society. 1982.

[2] Freedman M, Jaggi B Gp. Global warming, com-mitment to the Kyoto protocol, and accounting disclosures by the largest global public firms from polluting industries. The Interna-tional Journal of Accounting. 2005

[3] Deegan C, Gordon B. A study of the environmental disclosure and public policy pressure. Journal of Accounting and Public Policy . 1996. 